Na koniec ze wszystkıch słów powyższych przekonać się raczycie, czc1godni bıskupi i przewıelebnı kapłani! ıż Rada Narodowa postępować pragnie w duchu tej wiary, którą Wy opowiadacie, którą wyznawali nasi ojcowie i za którą krwí strumienı przelali, $w$ duchu tej naukı Zbawıciela, której treścią jest milość Boga I bliźniego.

Udzielcież Radzie w Waszym duchu działającej, udzielcie temu narodowı, który ona zastępuje, pasterskiego błogosławıeństwa i odrodzenie Polski, o pomyślność calego narodu, o pomoc $w$ prawnych usiłowaniach narodowej Rady, zanıeście gorące modły do Boga.

Czigodnych pasterzy do sworch trzód się oddalających, Rada żegna $z$ tem uczuciem, $z$ którem by odjeżdżających własnych ojców żegnała, a pozostających w jej gronle przewielebnych kapłanów do dalszych $\mathrm{z}$ sobą prac z dotychczasowa. gorliwoścxą uprzejmie i bratersko zaprasza.

Lwów, dnia 2 maja $1848 \mathrm{r}$.

(-) [Podpisali] Pod prezydencją Tytusa Dzieduszyckiego wszyscy przytomni czlonkowie Rady Narodowej w liczbie 40.

KS. JAN KOPIEC

\title{
KOLEJNA PRACA O HISTORIOGRAFII DIECEZJI *
}

Pierwsza książka z zakresu historiografii polskiej diecezji wyszła w r. 1926 spod pióra ks. Tadeusza Glemmy i traktuje o piśmiennictwie dotyczącym biskupstwa chełmińskiego od w. XVI do r. 1821, w którym nastąpiły ważne zmiany $w$ jego terytorium i organizacji. Stanowi drukowaną postać rozprawy doktorskiej, przygotowanej na Wydziale Teologicznym Uniwersytetu Jagiellońskiego pod kierunkiem ks. prof. dra Jana Fijalka ${ }^{1}$. Wywarła ona jak najlepsze wrażenie wśród ogólu historyków polskich.

Potem przez blisko 50 lat nie podejmowano $u$ nas podobnego tematu. Dopiero w r. $1972 \mathrm{ks}$. mgr lic. Tadeusz Krahel zdecydowal się na rozpoczęcie badań nad historiografią (archi)diecezji wileńskiej 2. Pracę napisał pod kier. ks. prof. dra Hieronima Eugeniusza Wyczawskiego na seminarium Nowożytnej Historii Kościoła Powszechnego i w Polsce w Akademii Teologii Katolickiej $w$ Warszawie $i$ przedstawil jako doktorską $w$ r. 1976. W trzy lata później zostala wydana drukiem. Autor dysertacji, kapłan archidiecezji w Białymstoku, już uprzednio (w latach 1970-1971) poświęcił diecezji wileńskiej swoją pracę magisterską i licencjacką ${ }^{3}$.

\footnotetext{
* Recenzja - $\mathrm{T}$. Krahel: Historiografia (archi)diecezji wileńsknej do 1939 roku, w: Studia 2 historii Kościoła w Polsce, t. 5, Warszawa ATK 1979, s. 1-179.

1 T. Glemma: Histortografia diecezji chetmińskie\} az po rok 1821, "Nova Pol. sacra", t. 2: 1926, s. 1-133 l odb. Kraków 1926, ss. 133 .

2 Tytul pracy ustalony jeszcze na semmarium Katedry Nauk Podstawowych i Metodologii Instytutu Historil Kościola KUL w pocz. $1972 \mathrm{r}$.

3 Por. T. Krahel: Schematyzmy Diecezji Wileńskiej jako zródlo historyczne, "Arch. BibI, Muz.", t. 38: 1979, s. 109-149, t. 39: 1979, s. 191-235, nadb. Lublin 1979, ss. [87].
} 
Biskupstwo wileńskie, stołeczne na Litwie, w czasach przedrozbiorowych Rzeczypospolitej bylo największą terytorialnie jej diecezją. Jakkolwiek biskupstwo wileńskie istnieje od r. 1387, a więc zastało kiedyś w Polsce diecezje starsze od siebie, to przecież ze względu na swoją rozległość, zlożoność narodowościową, wyznaniową, stosunki polityczne i uposażenie dostarcza ważnych tematów historycznych nie tylko z punktu widzenia kościelnego. Diecezja wileńska podlegała licznym zmianom terytorialnym i organizacyjnym, szczególnie po rozbiorach Polski - likwidacja za ces. Katarzyny II (1796 r.), przywrócenie za ces. Pawła I (1798), zmiana przynależności metropolitalnej z gnieźnieńskiej do mohylewskiej (1798), wyniesienie do rangi arcybiskupstwa i metropolii (1925). Od r. 1945 archidiecezja wileńska znajduje się w granicach Litewskiej i Białoruskiej SRR oraz PRL (część z Białymstokiem). Chocrażby przeto $\mathrm{z}$ wymienionych względów podjęcie trudu historiograficznego nad tą archidiecezją bylo uzasadnione.

$\mathrm{Na}$ temat dziejów (archi)diecezji wileńskiej napisano wiele. Zresztą badania historiograficzne posiadaja sens tylko w takiej sytuacji, kiedy uczony dysponuje bogatym dorobkiem w postaci wydanych źródel, monografii, opracowań, licznych przyczynków... Wtedy prace tego typu są nawet ważniejsze od poszczególnej historycznej monografii rzeczowej, miejscowej i osobowej, gdyz pozwalają ująć dotychczasowy stan badań oraz dostrzec problematykę wystarczająco opracowaną oraz tematy nie reprezentowane w warsztatach historyków. Przez taką refleksję latwiej przygotować syntezę calego zagadnienia. Takie też zadanie postawil sobie Autor omawianej pracy. Postanowil on zebrać wyniki dotychczasowego dorobku odnoszącego się do biskupstwa wileńskiego, poszczególnych aspektów jego funkcjonowania, ocenić wartość tych publikacji dla dalszych badań naukowych oraz odpowiedzieć na pytanie, czy już nadszedł odpowiedni czas na opracowanie wyczerpującej syntezy tego wielkiego zagadnienia, jakim jest przeszłość (archi)diecezji wileńskiej. Dla zrealizowania tego zadania musiał ks. dr Krahel zebrać pracowicie bardzo liczne publikacje w języku polskim i niemieckim, jak też w rosyjskim i litewskim. W celu przyswojenia sobie tego ostatniego uczęszczal na lektorat $w$ Uniwersytecie Warszawskim. W swych badaniach uwzględnił prace, które ukazały się drukiem zasadniczo do 1973 r. włącznie i dotyczą równiez Kościoła Rzymskokatolickiego na Litwie.

Swoją obszerną prace Autor rozplanował logicznie według postawionego sobie zamierzenia. Najpierw omówil historyków diecezji wileńskiej (s. 15-49), następnie wydawnictwa źródel (s. 50-74), potem opracowania pewnych okresów i problemów ogólnodiecezjalnych (s. 75-156), wreszcie wyciągnąl wnioski i postawił postulaty (s. 157-174). Całość dopełniają wstęp (s. 9-14), zakończenie (s. 175-176) oraz résumé (s. 177-179). W ten sposób mógł przejrzyście i całkowicie wyczerpać bogactwo dotychczasowego dorobku historyków.

Autorów-historyków uszeregował ks. Krahel według kryterium narodowościowego w kolejności: polscy, litewscy, inni (rosyjscy, bialoruscy, niemieccy). Starał się omówić syntetycznie osiągnięcia każdego z nich - na temat przeszlości biskupstwa wileńskiego - zarówno w edycjach źródel, jak tez $w$ opracowaniach, nawet drobnych. Ten podmiotowy uklad rozdziału pierwszego jest $\mathrm{w}$ pewnym sensie usprawiedliwieniem niektórych powtórzeń w rozdziale trzecim, który znowu ma układ rzeczowy według poszczególnych zagadnień i aspektów.

Zdaje się, że przyjęcie kryterium narodowościowego autorów - pewnie 
wygodniejsze do zrealizowania - mniej wyraźnie tłumaczy dorobek uczonych w zależności od miejsca i czasu ich pracy. Może owocniejszym zabiegiem metodologicznym w tych rozważaniach byłoby ujęcie poszczególnych historyków $\mathrm{w}$ ramach pewnych ośrodków naukowych czy instytucjonalnych, np. uniwersytety, instytuty historyczne, historycy-amatorzy. Wówczas może wyraźniej i konsekwentniej ukazałyby się zainteresowania danych ośrodków, własne ich metody badawcze, osiągnięcia oraz więcej lub mniej bogaty ich dorobek.

Z uznaniem należy podkreślić wykorzystanie przez Autora licznych kategorii źródel służących $\mathrm{w}$ historycznych badaniach nad przeszlością (archi)diecezji wileńskiej. Oprócz grup często wykorzystywanych przez historyków, jak zbiory dokumentów, akta działalności instytucji kościelnych, relacje o stanie diecezji, zwrócił on uwagę na inne rodzaje źródeł: kalendarzylki polityczne, schematyzmy diecezjalne, pamiętniki. W następstwie poszerzenia bazy źródlowej wskazał na możliwości czerpania $z$ innych, często jedynych informacji, potrzebnych do rekonstrukcji obrazu przeszłości kościelnej centralnej Litwy.

Dotychczasowy dorobek historyków ks. dr Krahel poddał klasyfikacji pod kątem jego przydatności i wartości naukowej. Dokonal tego poprzez zapoznanie czytelnika $\mathrm{z}$ podstawowym opisem pozycji, głównymı myślami autora, jego stanowiskiem oraz wnioskami, do których doszedl. Ustosunkowuje się do każdej pozycji, pozwalając z kolei odbiorcy na wypracowanie sobie sądu o danej pracy. W swojej ocenie Autor jest wymagający i jego selekcji szczęśliwie opiera się zaledwie część roztrząsanego piśmiennictwa. Jest to na pewno duże osiągnięcie ks. Krahela, albowiem każdy chętny badacz przeszłoścı Kościola wileńskiego może rozpoczynać od zapoznania się z jego ustaleniami i podług nich orientować ewentualne swoje zamiary.

Po przyjrzeniu się dotychczasowemu dorobkowi w dziedzinie kościelnej historiografii wileńskiej Autor doszedł do wniosku, że zagadnień nie opracowanych pozostaje niewiele, ale $z$ drugiej strony problemów wyjaśnionych dostatecznie i według wymagań dzisiejszej nauki również jest nie za dużo. Stąd w dalszym ciągu istnieje konieczność zajęcia się, mimo wszystko, licznymi aspektami życia kościelnego i religijnego na Litwie. $\mathrm{Z}$ zagadnień dotąd nie opracowanych wymienia ks. dr Krahel glównie problemy ustroju diecezji: początki i rozwój sieci dekanalnej, archidiakonat białoruski, oficjałaty okręgowe, kapituły kolegiackie (s. 158). Może ważnym zagadnıeniem, które należałoby opracować, są stosunki diecezji wileńskiej ze swoją metropolią w Gnieźnie. Wiadomo jak wielkie w Polsce uprawnienia posiadal metropolita wobec swoich sufraganów. Tendencje separatystyczne na Litwie nie należały do sporadycznych przejawów $w$ okresie przedrozbiorowym. Kilkakrotne projekty wyniesienia Wilna do rangi metropolii w XVII i XVIII w., uzurpacje biskupów wileńskich (Benedykt Wojna, Eustachy Wołłowicz, Abraham Wojna) do tytułu prymasa W. Księstwa Litewskiego z pewnością stanowią - wprawdzie negatywny - przejaw tych stosunków, które musiały mieć swoje odbicie w praktycznej realizacji zadań kościelnych tej diecezji.

Uwazna lektura rozprawy doprowadza do przekonania, że Autor wywiązal się $\mathrm{z}$ postawionego sobie zadania i swymi ustaleniami podzielił się $\mathrm{W}$ sposób przystępny $\mathrm{z}$ czytelnikami. Poprawny język $\mathrm{i}$ styl pracy $\mathrm{z}$ pewnością sprzyjają przyswojeniu jej treści.

Maszynopis dysertacji doktorskiej, który miałem do wglądu od jej Recenzenta, jest bogatszy $\mathrm{w}$ stosunku do wersji drukowanej o skrócony wykaz 
zbiorów źródeł względnie ich incipitów, o alfabetyczny indeks wydawców i autorów oraz o literaturę pomocniczą, w której pominięto kilka pozycji, dodanych potem przed drukiem. Opuszczone w publikacji elementy utrudniaja nieco dokładniejsze ogarnięcie zakresu poruszanych $w$ pracy autorów oraz ich dorobku.

Wykonanie druku jest na ogól poprawne, jednak czcionka drobna i ściśnięta męczy przy dłuzssym czytaniu. Ale każe to usprawiedliwić wykonanie rozprawy techniką malej poligrafii.

Największą satysfakcją dla Autora oraz wskaźnikiem pozytywnego odbioru jego pracy przez czytelników byłoby przystąpienie do realizacji postulatów, które we wnioskach wysunąl.

\section{JANUSZ ZBUDNIEWEK ZP}

\section{O MEDALACH I ODZNAKACH POLSKICH NA OBCZYŹNIE *}

Paradoksem wydaje się wspaniały rozwój sztuki medalierskiej, pamiątkowych odznaczen, a także bogaty dorobek hobbistycznych zdobyczy w dziedzinie filatelistycznej, nie posiadający jednak glębszego odniesienia w naukach pomocniczych historii. Niemalże wszystkie na różny sposób zaznaczyły się w dziedzinie wiedzy historycznej, lecz nie zdolały przekroczyć bariery kolekcjonerstwa. W ostatnich latach opublikowano $w$ kraju szereg prac z zakresu medalierstwa 1, falerystyki 2 i dziesiątki katalogów $z$ dziedziny filatelistyki. Piszą o nich najczęściej kolekcjonerzy z myślą o pomocy muzealnej lub handlowej, wyolbrzymiając ich znaczenie, względnie koszta produkcyjne, co pociąga za sobą snobistyczna gonitwę za ich zdobyciem. Niedostrzeganie ich $w$ ramach studiów historycznych budzi duże zdziwienie i skłania do apelu o zaznajomienie się $z$ ich geneza.

Medale $i$ odznaki są $w$ zasadzie prezentacja historycznych zdarzeń, jubileuszy, hołdem wobec zasłużonych postaci lub emblematem odróżniającym organizacje (w wypadku odznak). Wyobrażają doniosłe epizody historyczne, nieraz banalne uroczystości czy spotkania, zakuwane w szlachetnych nierzadko metalach, w ilościach hurtowych, obliczonych na zyski, albo w znikomej liczbie dla określonych odbiorców.

Zatem swoistym paradoksem jest fakt, że chociaż omawiane ekspozyty nie mają swojej wypracowanej lokaty w badaniach naukowych, to jednak stanowią przedmiot zabiegów licznych archiwistów i muzealników. Popularnością cieszą się przede wszystkim medale i odznaki obce, ponieważ krajowych emituje się zbyt dużo i z błahych często powodów. Wystarczy podać, że w latach 1946-1978 wybito 746 różnych wzorów medali w mennicy państwowej,

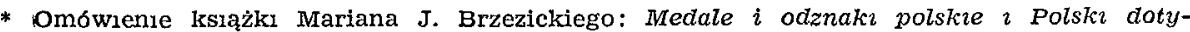
czqce bite poza Polska $w$ latach 1939-1977, Londyn, Instytut Polski i Muzeum im. Gen. Sikorskiego $19798^{\circ}$ Ss. 375, tabl. il.

1 Por. A. Więcek: Dzıeje sztuki medaliersikej $w$ Polsce, Warszawa, Wyd. Literackie 1972.

2 H. Holder: Ordery $i$ odznaczenia Polskiej Rzeczypospolitej Ludowej, Warszawa 1963. 